\title{
Graham Harman, Książę sieci: Bruno Latour i metafizyka, przeł. Grzegorz Czemiel, Marcin Rychter, Fundacja Augusta hr. Cieszkowskiego, Warszawa 2016, ss. 391
}

DOI: http://dx.doi.org/10.12775/RF.2017.018

\section{Wstęp}

Twórczość Latoura cieszyła się do tej pory największym zainteresowaniem ze strony socjologów i antropologów. Biorąc jednak pod uwagę rozmach oraz nowatorskość myśli francuskiego myśliciela, nie powinno dziwić, że jego ideami zainteresowali się również filozofowie. Ksia$\dot{z} e$ sieci. Bruno Latour i metafizyka autorstwa Grahama Harmana stanowi bodaj pierwszą monografię, w której idee francuskiego myśliciela stały się przedmiotem systematycznej refleksji metafizycznej. Autor jest bliżej znany polskiemu czytelnikowi z Traktatu o przedmiotach ${ }^{1}$ a także jako przedstawiciel $\mathrm{tw}$. realizmu spekulatywnego². Może to być o tyle zaskakujące, że z kolei tytułowy bohater jest kojarzony raczej z konstruktywizmem w filozofii nauki oraz refleksją nad konkretną praktyką badawczą - antropologią laboratorium. Latour jest jednym z najbardziej rozpoznawalnych współczesnych francuskich intelektualistów. Od końca lat 80. XX wieku jego idee stały się jednym z najważniejszych punktów odniesienia w szeroko rozumianej refleksji nad nauką. W języku polskim ukazały się dotychczas cztery książki Latoura ${ }^{3}$ oraz jego liczne artykuły. Skalę jego popularności wśród rodzimych badaczy od-

1 G. Harman, Traktat o przedmiotach, przeł. M. Rychter, PWN, Warszawa 2013.

2 Informacje na temat tego nurtu oraz jego głównych przedstawicieli czytelnicy i czytelniczki znajdą w: „Kronos” 2012, nr 1; zob. też M. Rychter, Coś z niczego. Krótkie wprowadzenie do realistycznego nihilizmu Raya Brassiera, „Kronos” 2011, nr 1.

3 B. Latour, Polityka natury. Nauki wkraczaja do demokracji, przeł. A. Czarnacka, Wydawnictwo Krytyki Politycznej, Warszawa 2009; Splatajac na nowo to, co społeczne. Wprowadzenie do Teorii Aktora-Sieci, przeł. K. Abriszewski, A. Derra, Universitas, Kraków 2010; Nigdy nie byliśmy nowocześni, przeł. M. Gdula, Oficyna Naukowa, Warszawa 2011; Nadzieja Pandory. Eseje o rzeczywistości w studiach na nauka, przeł. K. Abriszewski (red.) i inni, Wydawnictwo Naukowe UMK, Toruń 2013. 
zwierciedla również ukazanie się monografiii ${ }^{4}$ poświęconej szeroko dyskutowanej koncepcji, której jest on współautorem - Teorii Aktora-Sieci (Actor-Network Theory - ANT). Chociaż Latour kojarzony jest raczej ze studiami nad nauką i technologią (STS) czy antropologią laboratorium, to nie sposób zaprzeczyć, że jego idee są głęboko uwikłane w kwestie filozoficzne. Sam zresztą wyznaje w jednym ze swoich tekstów - „przede wszystkim jestem filozofem" ${ }^{5}$. Jakkolwiek francuski autor rozumie tę deklarację i swoją działalność akademicką, celem Harmana w Księciu sieci jest „sformułowanie spostrzeżeń Latoura w kategoriach odnoszących się do podstawowej struktury rzeczywistości jako takiej" (s. 12).

\section{Płaska ontologia}

Książka podzielona jest na dwie części: Metafizyka Latoura oraz Przedmioty i relacje. Pierwsza z nich składa się z czterech rozdziałów, a każdy $\mathrm{z}$ nich poświęcony jest jednej z książek francuskiego myśliciela. Amerykański autor wydobywa $\mathrm{z}$ nich idee o największym potencjale filozoficznym i pokazuje, że można z nich utworzyć spójną całość. Zabieg ten pozwala Harmanowi ulokować Latoura w szeregu największych twórców systemów metafizycznych.

Autor recenzowanej książki rozpoczyna od omówienia mniej znanego tekstu - Irréductions ${ }^{6}$. Ta licząca nieco ponad 80 stron praca jest o tyle zaskakująca, że swoją formą przypomina Traktat Wittgensteina, składa się również z serii punktów i podpunktów, a ostatni z nich ma numer 4.7.11. Amerykański autor rozwija myśl zawartą w pierwszej tezie Irréductions - „Nic samo z siebie nie jest ani redukowalne, ani nieredukowalne do niczego innego". Harman rekonstruuje na jej podstawie zasadnicze intuicje i pojęcia stojące za ANT, zarysowując przed czytelnikiem to, co bywa nazywane płaską ontologią (flat ontology $)^{7}$. Zgodnie z nią świat składa się z aktorów, ewentualnie aktantów - nowe pojęcie ma podkreślać, że mogą nimi być dowolne byty, np. rzeczy, postaci fikcyjne

${ }^{4}$ K. Abriszewski, Poznanie, zbiorowość, polityka. Analiza Teorii Aktora-Sieci Bruno Latoura, Universitas, Kraków 2008; zob. też E. Bińczyk, Inwazja ANT na "rynek" polski, „Teksty Drugie” 2010, nr 3, s. 329-337.

5 B. Latour, Coming out as a philosopher, "Social Studies of Science" 2010, no 4, s. 600 .

6 Praca ta nigdy nie ukazała się jako samodzielna pozycja. Stanowiła ona część książki Les Microbes: Guerre et paix, suivi de Irréductions (1984), przekł. ang. The Pasteurization of France (1988).

7 Abriszewski w swojej monografii dotyczącej ANT zauważa, że przyjęcie w polskiej literaturze nazwy "ANT" było dość przypadkowe i podaje inne będące w użyciu określenia: „ontologia aktanta-rhizomu” oraz „socjologia translacji”, K. Abriszewski, op. cit., s. 11. 
czy wydarzenia, albowiem być aktorem oznacza działać lub czynić różnicę. Pojęcie to może być jednak nieco mylące, dlatego że aktorzy nie są niezmiennymi w czasie, esencjonalnymi bytami. Określani są natomiast przez zajęcie miejsca w sieci relacji z innymi aktorami, co występuje wtedy, gdy sieci ulegają zmianie, albowiem wtedy zmieniają się również sami aktorzy. Każdy aktant jest tym bardziej obecny i wpływowy, w im większej liczbie relacji pozostaje z innymi. Latour myśląc o świecie, zdecydowanie odrzuca metaforę głębi czy hierarchii, jego ontologia może być zobrazowana przez jedną płaszczyznę, na której aktorzy poprzez różne konfiguracje tworzą określone zbiorowości. Wiele idei zawartych w Irréductions wpisało się na stałe w poglądy francuskiego pisarza i są one obecne w jego późniejszych książkach. Interesujące jest jednak to, że Harman sam przytacza słowa Latoura, w których bagatelizuje on, a przynajmniej podkreśla swój obecny dystans do "tych aforyzmów" (s. 21). Uwag takich w książce znajduje się więcej, dlatego od samego początku można odnieść wrażenie, że Harman wbrew samemu Latourowi, stara się przekonać nas do tego, abyśmy potraktowali autora $\mathrm{Ni}$ gdy nie byliśmy nowocześni jako twórcę systemu metafizycznego. Widać to wyraźnie w odmiennych sposobach traktowania przez obu myślicieli koncepcji „sieci”. Harmana interesuje sieć jako „obiekt” będący metafora która odzwierciedla strukturę świata. Z kolei przedmiotem zainteresowań Latoura są procesy wzmacniania i osłabiania relacji oraz ich praktycznych konsekwencji, sieć jest dla niego użytecznym, lecz niekoniecznym narzędziem konceptualizacji tych zagadnień.

Omawiając następną książkę - Science in Action, Harman wydobywa $\mathrm{z}$ niej dwa kolejne pojęcia: czarnej skrzynki i translacji. Pierwsze z nich jest odpowiedzią Latoura na doświadczenie stabilności aktorów, z którymi mamy do czynienia. Zdaniem francuskiego socjologa, niektórzy aktorzy zyskują status czarnych skrzynek, czyli czasowo ustabilizowanych i nieproblematyzowanych obiektów, które jednak zawsze mogą zostać otwarte, poddane rewizji i zmienione. $\mathrm{Z}$ kolei pojęcie translacji służy Latourowi do konceptualizacji relacji między aktorami. Jeśli bowiem aktor jest sumą swoich relacji z innym aktorami, to każda zmiana w obrębie tych relacji musi skutkować jego przekształceniem. Pojęcie translacji, lepiej niż pojęcie relacji, oddaje intuicję, że każde powiązanie jest $\mathrm{w}$ istocie przekształceniem. Nigdy nie mamy zatem do czynienia z czystym transferem informacji.

Następnie Harman omawia opus magnum Latoura - Nigdy nie byliśmy nowocześni. Amerykański autor podpisuje się pod przeprowadzonym w niej atakiem na fundamentalną kwestię konstytuującą myślenie nowoczesne - podział na kulturę i naturę. Francuskiemu autorowi nie chodzi tylko o to, by przestać ten podział puryfikować i wyostrzać, ale by zupełnie odwrócić kierunek naszego myślenia. Emblematyczną kategorią, która wyraża tę tendencję jest kategoria hybrydy lub inaczej qu- 
asi-przedmiotu. Według Latoura hybryda jest obiektem składającym się z serii nieheterogenicznych czynników. Pojęcia te, co trafnie zauważa Harman, mogą być dość mylące, ponieważ zakłada się, że taki hybrydowy obiekt jest częścią uprzednio danych i jednorodnych dziedzin (np. dziura ozonowa jako obiekt częściowo naukowy, a częściowo polityczny). Z perspektywy Latoura należałoby jednak odwrócić rozumowanie: złożone obiekty są punktem wyjścia, a wydestylowane obszary np. czysta nauka, polityka czy kultura są wtórne i stanowią sposób radzenia sobie z rzeczywistościa, który charakteryzuje, krytykowaną przez Latoura, myśl nowoczesnych.

Ostatnia z omawianych przez Harmana książek nosi tytuł Nadzieja Pandory. Eseje o rzeczywistości w studiach nad nauka. Zdaniem amerykańskiego filozofa, samo zawarcie w tytule pojęcia rzeczywistości „można odebrać jako jednoznaczny apel o $\mathrm{r}$ e a $1 \mathrm{i} \mathrm{z} \mathrm{m"} \mathrm{(s.} \mathrm{116).} \mathrm{Nie} \mathrm{oznacza}$ to jednak, że Latour rezygnuje ze swoich dotychczasowych poglądów. W dalszym ciągu utrzymuje on, że nie istnieją żadne nierelacyjne substancje, niezbywalne własności, a więc odrzuca ideę rzeczy samych w sobie, skrywających się rzekomo za sferą fenomenów. W jakim zatem sensie Latour jest realistą? Zdaniem Harmana podstawą rzeczywistości na gruncie poglądów francuskiego socjologa są relacje. Zgodnie jednak z zasadą równości wszystkich aktorów relacje nie są konstruowane społecznie, dlatego że ludzie nie są w żaden sposób uprzywilejowani w ich ustanawianiu. Widoczna od pierwszych stron niechęć Harmana do konstruktywizmu zostaje $\mathrm{w}$ tym miejscu $\mathrm{w}$ pełni wyartykułowana. Zakłada on bowiem, że konstruktywizm z założenia musi być społeczny, że to ludzie, kultura, gry językowe, dyskursy czy konwencje konstytuują rzeczywistość. A więc, jak sam stwierdza, „nie można też określić go [Latoura] mianem konstruktywisty, który wywodzi wszystko z wymiaru społecznego" (s. 122). Na gruncie poglądów współtwórcy Teorii Aktora-Sieci ludzie nie mają szczególnej pozycji w sieci bytów, sami bowiem, tak jak każdy inny aktor, składają się z sieci relacji. Z jednej strony można przyznać Harmanowi rację, że Latour uznaje relacje za coś istniejącego, chociaż można by mu zarzucić, że pojęcie istnienia ma nieco reifikujące konotacje, z drugiej strony, skoro wszyscy aktorzy podlegają nieustannym zmianom, wzajemnie się „przekonstruowują”, to nic nie stoi na przeszkodzie, aby pogląd taki nazwać konstruktywizmem, odrzucając rzecz jasna dookreślenie "społeczny". Nie chodzi tu jednak o to, by spierać się o słowa. Konstruktywistyczny sposób ujęcia stanowiska Latoura ${ }^{8}$ nie przechodzi Harmanowi ani przez chwilę przez myśl

8 Zdaniem Abriszewskiego ANT wykracza poza dualizm realizm - konstruktywizm, K. Abriszewski, op. cit., s. 98. Kwestia ta wymagałaby jednak szerokiej i dogłębnej analizy sformułowań poszczególnych stanowisk. 
z powodów, które dotąd jedynie sygnalizował, a które w pełni ujawnia dopiero w drugiej części książki.

\section{Latour metafizykiem?}

Druga część książki, oprócz tego, że jest obszerniejsza od pierwszej, stanowi zupełną zmianę perspektywy. Autor zajmuje w niej postawę krytyczną wobec poglądów Latoura, która pozwala mu płynnie przejść do wyłożenia własnych poglądów, określanych jako „filozofia zwrócona ku przedmiotom" (Object Oriented Ontology - OOO).

Zdaniem Harmana latouriańska koncepcja nawiązywania relacji między aktorami, który to proces odbywa się zawsze dzięki aktorowi pośredniczącemu, jest „bezprecedensową zdobyczą w długiej historii metafizyki” (s. 186). Nazywa ją „lokalnym okazjonalizmem” lub „przyczynowością zastępczą" i przeciwstawia okazjonalizmowi, w którym źródłem przyczynowości jest albo Bóg (Malebranche), albo nawyki umysłu (Hume). Trzeba przyznać, że Latour faktycznie proponuje opis pewnej mechaniki działania przyczynowości, ale jego koncepcja szybko popada w regres w nieskończoność. Pomiędzy A i B pośredniczy A', z kolei pomiędzy A i A' pośredniczy A" itd. Metafizyczna trywialność rozwiązania Latoura powoduje, że trudno wykrzesać z siebie tyle entuzjazmu co Harman i wraz z nim ogłaszać Latoura "pierwszym świeckim okazjonalistą" (s. 191) czy proklamować inaugurację latouriańskiej szkoły metafizycznej (s. 193). Te szumne określenia są o tyle zaskakujące, że Harman, w toku swej narracji, powoli, acz systematycznie odrzuca zasadnicze twierdzenia autora Nigdy nie byliśmy nowocześni, zastępując je własnymi. Co więcej, są one ich zupełną odwrotnością - esencje zamiast relacyjności, odróżnianie aktorów zamiast lokalizowania ich własności czy podział aktorów na rzeczywistych i zmysłowych. Harman utrzymuje, że mimo tych „niewielkich” korekt, w dalszym ciagu jest członkiem szkoły latouriańskiej. Pomocne w zrozumieniu tej rozbieżności mogą być słowa samego autora recenzowanej tu pracy, otóż, komentując uwagi Latoura dotyczące czasu, stwierdza on, że: „Latour idzie tu o jeden most za daleko i oddala się od sedna swojej filozofii (s. 204), „odrzucenie przez niego [Latoura] nierelacyjnych bytów jest niefortunnym ograniczeniem tłumiącym ducha tej filozofii" (s. 162). Jak widać, Harman rości sobie pretensje do tego, by wiedzieć lepiej od samego Latoura, co w jego filozofii się mieści, a co nie. Stwierdzenie, że radykalny relacjonizm nie jest w koncepcji autora Nadziei Pandory, jak powiedziałby Lakatos, twardym rdzeniem, wydaje się mocno przesadzone. Autor Księcia sieci odczytuje poglądy Latoura przez pryzmat swojej filozofii zwróconej ku przedmiotom, arbitralnie wskazując, które wypowiedzi francuskiego filozofa są „,retoryczną anomalią”, „pozornym konstruktywizmem” (s. 47) czy „taktyczną przesadą" (s. 207). Chociaż Harman stwierdza, że inaugura- 
torem filozofii skierowanej ku przedmiotom jest sam Latour, to trudno nie odnieść wrażenia, że myśl Latoura jest dla niego tylko pretekstem do tego, aby mógł wyrazić własne przekonania, które w niewielkim stopniu wspierają się na poglądach francuskiego myśliciela. Właściwie trudno wskazać cokolwiek, być może poza antyantropocentryzmem, co występuje w poglądach obu autorów.

Zdaniem Latoura, każdy aktor jest sumą relacji z innymi aktorami, tamci z kolei są sumą relacji między jeszcze innymi aktorami itd., wyraźnie widać, że mamy do czynienia z regresem w nieskończoność. Jeśli odczytywać ANT jako narzędzie analizy, a postulat „rozbieralności” aktorów jako wytyczną $w$ postępowaniu, to ów regres będący czysto teoretyczną konsekwencją zejdzie na dalszy plan, a samo narzędzie będzie po prostu albo skuteczne, albo nie. Jeśli jednak odczytywać tę koncepcję w perspektywie metafizycznej, napotkamy problem nierozstrzygalności, czy świat składa się ostatecznie z tego, co proste, czy z tego, co złożone. Harman stwierdza, że wspomniany regres „prowadzi stąd do piekła, a nawet dalej" (s. 175). Sam jednak zauważa, że Latour zdaje się nie przejmować konsekwencjami swojego stanowiska. Być może jest tak dlatego, że to właśnie on uprawia metafizykę, a nie Latour.

Spójrzmy na jeszcze jeden przykład. Harman zauważa, że skoro Latour może postulować złożoność wszelkich bytów w sensie metafizycznym, to dlaczego by nie „rozpocząć kampanii, w ramach której odzyskalibyśmy w s z y s t k i e tradycyjne pytania metafizyczne?" (s. 248). Widać tu wyraźna różnicę między Latourem, który bada konkretne sieci aktorów, wewnętrzne przekształcenia i ich praktyczne konsekwencje, a Harmanem, chcącym po prostu przywrócić do łask metafizyczną spekulację.

\section{Podsumowanie}

Ksiaże sieci to książka, którą trudno jednoznacznie zaklasyfikować. Z jednej strony jest ona omówieniem czterech książek Latoura i zawartych w nich tez, z których Harman stara się utworzyć obraz spójnej metafizyki. Z drugiej strony ponad połowa książki poświęcona jest krytyce myśli Latoura i wyłożeniu autorskich poglądów Harmana. Trudno więc nie odnieść wrażenia, że popularność Latoura stanowi dla amerykańskiego autora, któremu skądinąd nie sposób odmówić filozoficznej biegłości, jedynie pretekst do wyłożenia własnej koncepcji metafizycznej. Dlatego też trudno powiedzieć, do kogo recenzowana książka jest skierowana i komu można ją polecić. Jeśli bowiem kogoś interesują poglądy Harmana, to może on sięgnąc do jego książek, w których wykłada w dużo bardziej precyzyjny sposób własne poglądy metafizyczne. Można też sięgnąć do obszernych opracowań i analiz OOO. Jeśli kogoś interesują natomiast idee Latoura to, oprócz sięgania do tekstów samego autora, może on zajrzeć do licznych prac rekonstruujących jego poglądy. In- 
teresującą i w pewnym sensie konkurencyjną pozycja, w której zostały omówione idee francuskiego filozofa z perspektywy metafizycznej, jest Speculative Grace. Bruno Latour and Object-Oriented Theology Adama S. Millera ${ }^{9}$. Autor prezentuje w niej bardziej wyważone i uczciwe stanowisko względem poglądów Latoura. Miller stara się zaadaptować idee współtwórcy Teorii Aktora-Sieci do tego, by zmienić język teologii, nie wykazując usilnie wyższości swoich racji.

Latour w książce Nigdy nie byliśmy nowocześni zdecydowanie przeciwstawia się wyodrębnionym w okresie nowoczesności dyscyplinom, które redukują rzeczywistość do własnych kategorii. Można jednak spytać, czy metafizyka nie jest przypadkiem szczególnym? Na szczęście nie jest to kwestia, którą musimy tu rozstrzygnąć. Zdaje się, że Latour też nie jest nią zainteresowany. We wspomnianej wyżej książce stwierdza on, że "studia nasze nie dotyczą jednak natury wiedzy czy rzeczy samych w sobie, ale pokazuja, jak badane przedmioty uwikłane są w rozmaite kolektywy i podmioty" (s. 13). Można więc na koniec zapytać: czy Latour zbudował system metafizyczny? Co to w ogóle znaczy zbudować system metafizyczny? Jeśli Latour go zbudował, to czy o tym wie? Sytuacja ta aż nazbyt przypomina scenę ze sztuki Moliera, w której to właśnie filozof poucza tytułowego bohatera, że gdy mówi, to mówi prozą. Jej parafraza $\mathrm{z}$ Latourem w roli głównej brzmiałaby tak: Daje słowo, zatem ja już przeszło czterdzieści lat uprawiam metafizykę, nie mając o tym żywego pojęcia! Jestem panu najszczerzej obowiazany, żeś mnie pouczył.

Krzysztof Tarkowski Uniwersytet Mikołaja Kopernika, Toruń e-mail: krzysztof.tarkowski@gmail.com

9 A. S. Miller, Speculative Grace: Bruno Latour and Object-Oriented Theology, Fordham University Press, New York 2013. 